\title{
TRZY WYMIARY TOTALNOŚCI. TWÓRCZOŚĆ LIDII GINZBURG
}

Katarzyna Roman-Rawska

Polska Akademia Nauk

\section{/// Przedmiot i podmiot badania}

W rozważaniach na temat roli figury intelektualistki totalnej w Europie Wschodniej nie sposób pominąc kontekstu rosyjskiego. Debata na temat tamtejszej inteligencji toczy się z różną intensywnością niezmiennie od drugiej połowy XIX wieku. W bogatej literaturze przedmiotu problematyzującej warstwę społeczną inteligencji z różnych perspektyw: socjologicznej (Zarycki 2008; Kochetkova 2010; Toŝenko 2019), historycznej (Read 1979; Sdvižkov 2011; Nahirny 2018), kulturoznawczej (Uspenskij 1997) czy publicystycznej (Gessen 1997), spotkać się można z niewypowiedzianym zazwyczaj wprost założeniem o totalności tego zjawiska, która realizuje się m.in. poprzez jego unikatowość (czyli ograniczenie do kontekstu Europy Wschodniej, a przede wszystkim Polski i Rosji, oraz odróżnienie od zachodnich intelektualistów), eteryczność (trudno jednoznacznie określić granice tej grupy), patetyczność (poczucie doniosłości i odgrywania kluczowej roli w przełomowych momentach dziejów) oraz, co interesuje mnie w tym artykule najbardziej, wewnętrzną i nierozerwalną sprzeczność.

Co istotne, w tej samej literaturze przedmiotu czytamy o rosyjskiej inteligencji jako o zjawisku kolektywnym, rzadziej natomiast proponuje się analizę twórczości przedstawicieli tejże inteligencji w poszukiwaniu praktycznej realizacji założeń mitycznej inteligenckości (nie mam tu oczywiście na myśli idealizujących i mitologizujących biografii). W niniejszym artykule przyjrzę się splotowi trzech totalności, które obecne są w życiu i twórczo- 
ści słabo znanej w Polsce myślicielki i pisarki Lidii Ginzburg (1902-1990). Artykuł można traktować zatem jako wysiłek podjęty w celu wypełnienia dwóch luk - jest to z jednej strony próba zdefiniowania wspomnianej totalności w praktyce twórczej czy też intelektualnej indywidualnej przedstawicielki inteligencji w Rosji, z drugiej natomiast przybliżenie polskiemu odbiorcy samej postaci oraz wybranych aspektów jej bogatej myśli.

Wewnętrzna i nierozerwalna sprzeczność, czyli jedna z odsłon totalności w dyskursie inteligenckim oraz w dyskursie o inteligencji, której będę się przyglądać, przejawia się m.in. w dążeniu do kompletności i otwartości jednocześnie, pokazywaniu szerokiej panoramy zjawisk przy jednoczesnym skupieniu na detalu, sięganiu po przeciwstawne idee, zachowaniu swobody myśli i równolegle dyscypliny intelektualnej, a także konsekwentnym zaufaniu do własnej wyobraźni - nawet w warunkach instytucjonalnego impasu. Zakres tematów i wątków podejmowanych przez Lidię Ginzburg jest szeroki i obejmuje jednocześnie badania nad literaturą klasyczną oraz współczesna, światową i narodową (rosyjska), liryką i epika, psychologia oraz emocjami konkretnej postaci i poszukiwaniem typów społecznych na tle przemian historycznych. Ginzburg zakorzeniona jest teoretycznie w awangardowym formalizmie i w odrzucanym przez jego przedstawicieli społecznym paradygmacie, a w warunkach skrajnej niepewności i strachu potrafi zamienić się w uważną analityczkę i obserwatorkę rzeczywistości. Taka totalność oparta na sprzecznościach nie zakłada jedynie dostrzegania prostych dychotomii, lecz mówienie o nich w sposób dialektyczny. Jest ona zdolnością do przechodzenia od jednej perspektywy do drugiej oraz swobodnego poruszania się między dyscyplinami. W przypadku Lidii Ginzburg mówić można o przynajmniej trzech wymiarach zdefiniowanej wyżej totalności, które jej towarzyszyły, wpływały na nią, były przez nią poddawane dogłębnej analizie i zaowocowały niebanalnym dorobkiem naukowym. To właśnie te wymiary, a więc totalność otoczenia instytucjonalnego, totalność doświadczeń biograficznych oraz totalność myśli, będą przedmiotem moich dalszych rozważań.

\section{/// Człowiek przy biurku}

Złożoność i wielowymiarowość teorii Lidii Ginzburg bywa zestawiana z koncepcjami takich uczonych jak Michaił Bachtin, Jurij Lotman czy Olga Freudenberg1. Ginzburg została odkryta późno, bo na początku lat 70. XX

\footnotetext{
${ }^{1}$ Jak słusznie zauważa Wincenty Grajewski we wstępie do Semantyki kultury Olgi Freudenberg interesujące mogłoby być porównanie losów obu myślicielek, m.in. z powodu podobieństw biogra-
} 
wieku w Związku Radzieckim oraz ponownie w Rosji i w nauce anglosaskiej w pierwszej dekadzie XXI wieku. Bez wahania można określić ją mianem socjolożki literatury oraz badaczki aspektów psychologicznych w literaturze, a także teoretyczki kultury². Urodziła się w 1902 roku w Odessie, w rodzinie nazywana była Lusią ${ }^{3}$. Jej ojciec Jakow Ginzburg był inżynierem, właścicielem przedsiębiorstwa i laboratorium z branży piwowarskiej. Zmarł już w 1909 roku, a po jego śmierci opiekę nad rodziną przejął jego brat, również inżynier chemik, Mark Ginzburg. Matka, Raisa (Rachel) Ginzburg, prowadziła dom. Zmarła z powodu dystrofii głodowej w 1942 roku w trakcie blokady Leningradu. Lidia Ginzburg miała także starszego brata Wiktora, znanego pod pseudonimem Tipot ( $\mathrm{z}$ ang. tea $p o t$ ) dramaturga, reżysera teatralnego oraz współzałożyciela moskiewskiego teatru satyry.

$\mathrm{Na}$ początku lat 20. XX wieku wraz z matką przeniosła się do Leningradu, gdzie początkowo, idąc w ślady ojca i wuja, studiowała chemię. Już w 1922 roku rozpoczęła studia w tamtejszym Instytucie Historii Sztuk gnieździe rosyjskiego formalizmu. Studiowała m.in. u Borisa Ejchenbauma i Jurija Tynianowa, a to doświadczenie traktowała jako „zmieniające życie” (Ginzburg 2002: 56). W tym samym Instytucie pracowała naukowo i pisała doktorat do jego zamknięcia w 1931 roku. Obroniła rozprawę doktorska w 1940 roku na bezpieczny temat dotyczący twórczości Michaiła Lermontowa, w przeddzień setnej rocznicy śmierci poety. Lata 30., a więc czas stalinowskich czystek i represji oraz petryfikacji pola literackiego, przetrwała na uboczu.

Lata 40. i 50. to dla niej dalsze doświadczenie marginalizacji, tym razem w warunkach oblężonego Leningradu - gdzie pracowała jako redaktor w komitecie ds. radia - oraz powojennego stalinizmu, kiedy - mimo trwającej jawnie antysemickiej kampanii pod hasłem walki z kosmopolityzmem - do 1950 roku pracowała na Uniwersytecie w Pietrozawodsku. Dopie-

ficznych (Grajewski 2005: XIII-XIV). Dodam, że równie wartościowe byłoby zestawienie myśli obu intelektualistek, co początkowo było założeniem tego artykułu. W trakcie kwerend przygotowujących grunt pod niniejszy tekst okazało się jednak, że spuścizna Lidii Ginzburg, w odróżnieniu od prac Olgi Freudenberg, jest polskiemu odbiorcy dużo słabiej znana. Dotychczas na język polski przetłumaczone zostały jedynie fragmenty jej wspomnień z czasu blokady Leningradu (zob. Ginzburg 2013). Również opracowań teoretycznych dotyczących jej dorobku lub chociażby wybranych aspektów jest niewiele (zob. Pawletko 2011; Komisaruk 2014). Inaczej sprawa wygląda w literaturze rosyjsko- i anglojęzycznej. Tu zainteresowanie koncepcjami Ginzburg od lat 90 . jest stabilne i chociaż nie jest też przesadnie duże w sensie ilościowym, to można je uznać za wielowymiarowe i kompleksowe (zob. np. Van Buskirk, Zorin 2012; Savickij 2013; Van Buskirk 2016).

${ }^{2}$ Lidia Ginzburg najbardziej nie lubiła, kiedy określano ją mianem literaturoznawczyni. Termin ten był dla niej nadmiernie redukcjonistyczny, szczególnie w kontekście szerokiego spektrum jej zainteresowań (zob. Van Buskirk 2016: 36).

${ }^{3}$ Notka biograficzna przygotowana została w oparciu o informacje z: Kušner 2002; Van Buskirk, Zorin 2012; Savickij 2013; Van Buskirk 2016. 
ro chruszczowowska odwilż dała jej możliwość powrotu do aktywności publikacyjnej, a już w 1957 roku wyszła jej praca poświęcona twórczości Aleksandra Hercena, stanowiąca podstawę habilitacji.

Lata 60. i 70. to czas jej częściowego powrotu do życia społecznego. Wtedy właśnie wzrasta zainteresowanie jej osobą wśród pokolenia inteligencji lat 60. (szestidiesiatnikow), wtedy też Ginzburg publikuje swoje trzy duże i znaczące dzieła - O lirikie (O liryce) (1964), O psichotogiczeskeoj prozie (O prozie psychologicznej) (1971) oraz O litieraturnom gieroje (O bohaterze literackim) (1979). Jednak dopiero lata 80. wraz z pieriestrojka daja jej możliwość wydania pisanych do szuflady wspomnień i zapisków z lat 20. i 30. oraz dziennika z blokady Leningradu, a także jej dotychczas niepublikowanej prozy. Ostatnia praca, złożona z niepublikowanych wcześniej dzieł i wydana za jej życia w 1989 roku, nosiła tytuł Czełowiek za pis'miennym stołom (Człowiek przy biurku). Lidia Ginzburg zmarła w lipcu 1990 roku podczas pracy nad kolejnymi publikacjami.

\section{/// Totalność: wymiar 1. Początek i koniec Związku Radzieckiego}

Lidia Ginzburg była świadkiem narodzin i śmierci Związku Radzieckiego wraz ze wszystkimi najważniejszymi etapami jego rozwoju i degradacji. Doświadczyła wszystkiego, czego mógł doświadczyć człowiek o jej pochodzeniu i statusie społecznym w ZSRR: poczucia triumfu związanego z rewolucjami, rozczarowania nagła zmianą kursu politycznego z progresywnych idei w kierunku betonowego państwa biurokratycznego, wielkiego terroru lat 30., głodu w czasie blokady Leningradu, dalszych represji stalinowskich na tle narodowościowym, nadziei okresu „odwilży” po roku 1956, bezwładu i bezruchu okresu stagnacji lat 70. oraz niejednoznaczności i chaotyczności pieriestrojki. Ginzburg była jednak uczestniczką-obserwatorka, nie zaś ofiarą tych wydarzeń, a szczególnie interesowało ją to, co działo się w czasie pomiędzy (promię̧utok wriemieni).

Sama siebie nazywała - choć nie wprost, co jest charakterystyczne dla jej sposobu narracji o sobie samej, jako o typowej przedstawicielce swojego pokolenia - „człowiekiem lat 20.” (Ginzburg 2002: 192)4. Oznaczać to miało, że jej myśl ukształtowało zafascynowanie ideami rewolucyjnymi i politycznym radykalizmem, a sama „,...] czuła się potomkiem przewrotu rewolucyjnego" (Van Buskirk, Zorin 2012: 3). Idee Ginzburg formowały się w szerokim spektrum relacji do różnych środowisk i instytucji. Z jednej

${ }^{4}$ Fragmenty i tytuły prac Lidii Ginzburg oraz badaczy jej spuścizny, które nie były dotychczas tłumaczone na język polski, występują w artykule w tłumaczeniu autorki artykułu. 
strony myślicielka była w pełni zaangażowana w działalność grup artystycznych i naukowych rosyjskiego modernizmu i awangardy lat 20., w tym w prace OPOJAZ-u (Obszczestwo izuczenija poeticzeskogo jazyka), czyli Towarzystwa Badań Języka Poetyckiego, które stanowiło centrum kręgu lingwistyczno-literaturoznawczej szkoły formalnej związanej z ideami futurystycznymi. Brała także udział w spotkaniach generacji młodych formalistów (Madoformalisty), uczniów formalistów starszych, bywała wśród akmeistów, zwolenników kierunku opozycyjnego wobec futuryzmu. Z drugiej strony to właśnie wielowymiarowa marginalizacja ${ }^{5}$, jakiej doświadczała od początku lat 30., stała się „kluczowym czynnikiem wpływającym na literacką tożsamość i wizerunek siebie samej (self-image) Ginzburg” (tamże: 6). Ginzburg dość szybko zresztą pojęła, że formalne metody interpretacji literatury są dla niej niewystarczające, co zaowocowało wypracowaniem jej unikatowego podejścia. Niemniej, paradoksalnie, „chociaż osobiście była oddalona, pozostawała blisko, a także była lojalna wobec nich i ich tradycji intelektualnej przez całe życie, choć zmniejszyło to jej szanse na sukces zawodowy" (tamże: 4).

Te zmniejszone szanse na sukces zawodowy dosłownie oznaczały radykalną zmianę w statusie społecznym. Lata 30. w Związku Radzieckim to czas brutalnego zrównywania pluralizmu środowisk intelektualnych i twórczych poprzez kampanie propagandowe w nie wymierzone oraz konkretne instytucjonalne regulacje skutkujące przejęciem pełnej kontroli państwa nad polem literackim ${ }^{6}$. W 1931 roku, postanowieniem Rady Komisarzy Ludowych RFSRR, faktycznie zlikwidowano Instytut Historii Sztuk, oficjalnie, pod hasłem reorganizacji, przekształcając go w inną jednostkę (Kumpan 2011). Po przekształceniu tej instytucji Ginzburg pracowała jako lektorka na rabfaku', czyli instytucji, która miała za zadanie przygotować robotników i chłopów na studia - w Wojskowym Instytucie Sił Powietrznych, oraz w kółku literackim fabryki produktów gumowych „Czerwony Trójkąt”. W 1935 roku wstapiła do powstałego rok wcześniej

\footnotetext{
${ }^{5}$ Jak pisze Van Buskrik, „Była marginalizowana jako pisarka, która nie mogła nawet aspirować do opublikowania swoich prac, jako uczona bez regularnej pracy w państwie totalitarnym, jako skrywająca swoją orientację seksualną lesbijka w coraz bardziej homofobicznym społeczeństwie, jako Żydówka w kraju, gdzie nieco zawoalowany antysemityzm stopniowo stawał się częścią oficjalnej ideologii, a dyskryminacja ze względu na pochodzenie narodowe przekształcała się w oficjalną praktykę" (Van Buskirk 2016: 31). Każdemu z tych wymiarów marginalizacji Ginzburg poświęciła po jednym eseju.

${ }^{6}$ Aktem ostatecznego przejęcia kontroli państwa nad polem literackim było utworzenie w 1934 roku Związku Pisarzy ZSRR oraz wpisanie w jego statut socrealizmu jako obowiązującej metody twórczej.

${ }^{7}$ Rabfak to skrót od rabocæij fakultet - w dosłownym tłumaczeniu jest to Wydział Robotniczy.
} 
Związku Pisarzy ZSRR, czyli instytucji, która de facto spetryfikowała pole literackie w ZSRR. Ginzburg, chociaż była jak najdalsza od ideologicznego zaplecza tej instytucji - nie poddawała nigdy refleksji sensowności lub bezsensowności wprowadzenia socrealizmu jako obowiązującej metody twórczej, a zwyczajnie zbyła ten fakt milczeniem - nigdy nie starała się jednak tego betonu kruszyć, a lata 30. traktowała jako doświadczenie zetknięcia z innym wymiarem instytucji, a nawet, jak ują to Stanisław Sawicki, postrzegała swoje kontakty z państwem totalitarnym jako „egzystencjalne doświadczenie intelektualne" (Savitsky 2012: 263). Poszukiwała miejsca dla siebie i swojej myśli w nowej konfiguracji i pozostała na pozycji obserwatorki, ale jednocześnie uczestniczki zdarzeń.

Przejawem tych poszukiwań (Savickij 2013: 104) oraz zwyczajnej materialnej konieczności (Van Buskirk 2016: 95) było przyjęcie przez nią zlecenia na napisanie powieści dla młodzieży. W efekcie Agienstwo Pinkiertona (Agencja Pinkertona) opublikowana w 1932 roku nie zyskała większego rozgłosu i uznania, a autorka traktowała tę powieść z dystansem, rozumiejąc jednocześnie, że tak będą wyglądały lata 30. Jak twierdzi Van Buskirk, pracę traktowała jako "nie swoją" oraz „świadome literackie fałszerstwo”, a fakt, że nie mogła wypowiedzieć się wprost, tylko zmuszona była podążać za abstrakcyjnymi regułami gatunku, spowodował, że już do tej formy literackiej nigdy nie wróciła (tamże: 95-96). Tu znowu mamy do czynienia ze sprzecznością, definiującą totalność jej instytucjonalnego zakorzenienia. Ginzburg, nawet starając się być częścią nowego porządku symbolicznego, nigdy nie potrafiła go w pełni zaakceptować.

Nie oznacza to jednak, że po prostu pokornie znosiła okoliczności zewnętrzne. Porażka projektu zamawianej powieści młodzieżowej, rozpad więzi, którego doświadczyła, oraz bezpośrednie represje, jakie ją dotknęły w 1933 roku, kiedy była aresztowana i przesłuchiwana w sprawie Wiktora Żyrmunskiego (jednego z jej nauczycieli akademickich), sprawiły, że niemal całkowicie wycofała się z robienia zapisków, a więc charakterystycznego dla niej w latach 20. sposobu utrwalania myśli i wspomnień. Nie przestała jednak pisać całkowicie. W tym czasie dalej poszukiwała sposobu analizy i interpretacji literatury i społeczeństwa, w duchu zapoczątkowanego przez nia pod koniec lat 20. zwrotu psychologiczno-socjologicznego. $\mathrm{Na}$ przełomie 1979 i 1980 roku opublikowała dwa znamienne eseje Pokolenije na poworotie (Pokolenie na zakręcie) oraz I zaodno s prawoporiadkom (Zgodnie w imię porządku), w których sama przeanalizowała mechanizm pozwalający inteligencji lat 30. pracować, żyć i tworzyć w warunkach narastającego terroru i ucisku instytucjonalnego. 
W pierwszym z nich Ginzburg snuje refleksję także na temat podziałów wewnątrz inteligencji, problematyzując tym samym, choć nie wprost, również swoje miejsce w tym nowym skomplikowanym układzie. Myślicielka zastanawia się tym samym nad reprezentatywnością swojej postawy dla całego pokolenia ówczesnej inteligencji, ukształtowanej na ideach rewolucyjnych lub w opozycji do nich. Co jednak istotne, mimo potencjalnie różnych, a nawet przeciwstawnych dróg, jakie obierali poszczególni przedstawiciele tego pokolenia, Ginzburg nie mówi o nim jako o rozbitym czy podzielonym, ale jako o wyrastającym z tego samego korzenia i spójnym w swojej niespójności. Jak pisze, „[t]rendy pochodziły z różnych sfer, ale miały też ze sobą coś wspólnego. Wspólna była idea bezgranicznego rozwoju osobowości. Cała rosyjska awangarda spoglądała na rewolucję" (Ginzburg 1987: 314).

Według Ginzburg pokolenie to łączy zatem wewnętrzna i nierozerwalna sprzeczność, która jest fundamentem i dystynkcja całej grupy: „Człowiek działa pod wpływem różnych tendencji swojej epoki, które są jednocześnie uwewnętrzniane. Tak więc połączenie tradycji narodnickich, a nawet Narodnej Woli z awangardyzmem i modernizmem, zrodziło na początku XX wieku nową formację inteligencką, która wystraszyłaby nawet najuczciwszych narodników lat 70. XIX wieku" (tamże: 314). Pisarka podkreśla też, że w związku z wpisaną w tożsamość nowej inteligencji przeciwstawnością, niczym zaskakującym nie jest, że: „Owo centrum wartości (cennostnyj centr), w którym indywidualizm i modernizm przecinają się z umiłowaniem ludu (narodolubije), rozszczepia się na dwa centra, protagonistów i antagonistów" (tamże: 317).

$\mathrm{Na}$ tej podstawie Ginzburg klasyfikuje ówczesne postawy przedstawicieli jej pokolenia inteligencji i rozdziela je na trzy najbardziej rozpowszechnione, czyli: zwolenników, którzy szli do komsomołu i dobrze odnajdywali się w późniejszych strukturach; przeciwników, którzy emigrowali lub pozostawali we frondzie; oraz tych, pozostających w stanie synkretycznym (sinkrieticzeskoje sostajanije) (tamże: 318). Ostatniej grupie poświęca najwięcej uwagi, dając tym samym implicite do zrozumienia, że sama do pewnego stopnia identyfikuje się z tą częścią przed- i porewolucyjnej inteligencji radzieckiej, nazywając siebie typowa przedstawicielką tej generacji. Ów typ synkretyczny jej zdaniem jest „znaczący” i „powszechny”, a w niektórych przypadkach przekształca się z czasem w poputçika. Jak dalej pisze: „To on właśnie został głównym bohaterem epopei chwiejnych watpliwości, zbliżeń i oddaleń, inteligenckiej epopei lat 20. i częściowo 30. Różne idee mieszały się wtedy i przejawiały się na wiele sposobów w tym fermencie. 
Ale najważniejsze było odnalezienie punktu styczności (toczlea sowmestimosti)" (tamże: 318).

Bardzo interesująca wydaje się w tym kontekście także podejmowana przez nia próba wyjaśnienia, jakie społeczno-psychologiczne mechanizmy stały za potrzebą odnalezienia wspomnianego punktu styczności, który pozwalałby inteligencji wchodzić w stan synkretyczny. Wśród nich Lidia Ginzburg wspomina o pragnieniu życia i działania, niezależnie od uświadomionych i nieuświadomionych pułapek, jakie to pragnienie za sobą niesie. To indywidualne pragnienie przeplatało się ze zbiorowym afektem twórczym, stymulowanym przez atmosferę ożywienia intelektualnego: „Wtedy było dużo talentu i siły, a siła chciała się manifestować. Pomogła w tym hipnotyzująca i zachwycająca atmosfera [początku] lat 30. Ten zachwyt pozwalał żyć, a nawet urozmaicał aktywność życiową, dlatego był tak prawdziwy i szczery zarówno dla mas, jak i najbardziej wyrafinowanych intelektualistów" (tamże: 318). To pragnienie życia i działania było jednak krok po kroku dławione przez rozrastający się aparat biurokratyczny, wkraczający gwałtownie w latach 30. w środowiska twórcze, przez późniejsze represje oraz doświadczenia wojenne, o czym mowa będzie niżej.

Po zakończeniu II wojny światowej, w latach 1947-1950, dzięki temu, co zostało z jej przedwojennych relacji społecznych, pracowała na Uniwersytecie w Pietrozawodsku, na który zaprosił ją Eleazar Mieletinski, niedługo potem, w 1949 roku, represjonowany i skazany na 10 lat łagru w ramach stalinowskiej kampanii antysemickiej prowadzonej w ZSRR pod hasłem walki z kosmopolityzmem. Wtedy też ponownym represjom poddany został Boris Ejchenbaum. Według badaczy spuścizny Ginzburg tylko śmierć Stalina uratowała ją samą przed represjami, które miały być kontynuowane tym razem wobec przedstawicieli literaturoznawczych środowisk akademickich po zakończeniu sprawy tzw. spisku lekarzy kremlowskich.

Śmierć Stalina oraz chruszczowowska „odwilż” zmieniły wszystko diametralnie. Pokolenie inteligencji lat 60. szybko potraktowało Lidię Ginzburg jako żywą legendę (Kumpan 2016), mityczną przedstawicielkę awangardy lat 20. Szybko jednak sama Ginzburg odrzuciła ten romantyzujący paradygmat, pozycjonując się raczej jako intelektualistka tu i teraz. Wtedy zaczęto ją traktować raczej jako autorytet, któremu udało się stworzyć kompletną i spójną teorię w warunkach skrajnego chaosu i fragmentaryczności, funkcjonować zarówno w ramach porządku instytucjonalnego ZSRR, jak i poza nim, a także stworzyć figurę intelektualistki totalnej w wymiarze instytucjonalnym. 


\section{/// Totalność: wymiar 2. Zapiski człowieka oblężonego}

Oprócz doświadczenia skutków funkcjonowania w państwie totalitarnym, Lidia Ginzburg przeżyła także wojnę, a dokładnie blokadę Leningradu w latach 1941-1944, za co zresztą to samo państwo nagrodziło ją medalem „Za obronę Leningradu”. Przez cały okres oblężenia pracowała w komitecie ds. radia w sekcji zajmującej się literaturą. Okres wojenny był dla niej „wytchnieniem psychicznym po Wielkim Terrorze końca lat 30.” (Van Buskirk 2016: 32), a sama praca w komitecie - „cennym doświadczeniem spotecznej prrydatności (social relevance - socyalnaja primienimost') i szansa, by choćby przez chwilę poczuć akceptację $\mathrm{w}$ ramach istniejącego porządku istnienia (order of existence)" (tamże: 33). Również wspomnienia z tego czasu nie zostały przez nia potraktowane w sposób klasycznie retrospektywny, lecz stały się pretekstem do wnikliwej obserwacji i analizy typów społecznych w określonych warunkach historycznych. Ginzburg, również w tym wymiarze totalności - a więc dotyczącym bezpośrednio jej własnej biografii - porusza się pomiędzy tym, co intymne, indywidualne, a tym, co nazwać można doświadczeniem zbiorowym. Za cel stawia sobie „[...] pokazać nie tylko życie społeczności miasta w blokadzie, ale i byt pojedynczego człowieka. Jest to człowiek sumaryczny i umowny (dlatego nazywam go En), inteligent w szczególnych okolicznościach" (Ginzburg 2013: 172).

Zapiski z czasu oblężenia przygotowywała do druku w okresie odwilży, ale nie zdążyła ich wydać przed ponownym zamrożeniem pola literackiego. Z szuflady mogła je wyją́ dopiero w czasie pieriestrojki, a pierwsze fragmenty zostały opublikowane w 1984 roku w czasopiśmie „Niewa”. Wtedy też, w wieku 82 lat, Lidia Ginzburg miała po raz pierwszy szansę wyjść poza kręgi inteligenckie i dotrzeć ze swoim przekazem do masowego w tym czasie czytelnika „grubych" czasopism literackich ${ }^{8}$. Praca nad Zapiskami człowieka oblę̇onego - kontynuowana również bezpośrednio po wojnie - dała jej poczucie zrozumienia, czym tak naprawdę warto się zajmować i dlaczego dotychczas intuicyjnie ciążyła w kierunku typu bohaterów, którzy są ,ludźmi dwóch wojen i czasu pomiędzy nimi (promię̧utok). [...] dopiero teraz zrozumiały jest sens historyczny tego fantomowego pokolenia i symbolika jego losu" (Ginzburg 2011: 303, 294, za Van Buskirk, Zorin 2012: 9). W wielu fragmentach przywoływanych niżej widoczne jest także pożegnanie czy też rozliczenie Lidii Ginzburg z ideami szkoły formalnej.

${ }^{8}$ W oryginale tołstyj żurnat - popularne w Związku Radzieckim czasopisma literackie o dużej objętości, które szczególnie w czasie pieriestrojki stanowiły symbolicznie istotną platformę debaty publicznej. 
Wspomniana tu już społeczna przydatność - w polskim tłumaczeniu powszechna powinnosí́ - była jednym z centralnych pojęć Zapiskón čłtowieka obleżonego. Swoje przemyślenia Ginzburg otwiera definicją tego pojęcia:

Kto miał siłę czytać, ten w oblężonym Leningradzie zaczytywał się w Wojnie i pokoju. Tołstoj raz na zawsze zdefiniował męstwo człowieka czyniącego swa powszechna powinność wobec wojny narodowej. Uzmysłowił, że owładnięci tą powinnością ludzie kontynuuja ją nawet mimowolnie, nawet wtedy, gdy - wydawałoby się - zajęci są zwykłymi, codziennymi sprawami. Mieszkańcy okrążonego Leningradu pracowali (póki mogli) i ratowali, jeśli mogli, od śmierci głodowej siebie i swoich bliskich. I, w ostatecznym rozrachunku, to także było częścią tej powszechnej powinności, jako że na przekór wrogowi miasto, które ten wróg chciał unicestwić, żyło (Ginzburg 2013: 171).

Warto tu zwrócić uwage, że dla Lidii Ginzburg społeczna przydatność była siłą z jednej strony pojawiającą się w okolicznościach ekstremalnych, z drugiej natomiast, przejawiającą się w najbardziej zwykłych czynnościach życiowych. Owa zwyczajność dawała mieszkańcom oblężonego Leningradu spokój, który z czasem zamieniał się w powtarzalny rytm i rytuał: „Spokój stał się ogólnym, przeciętnym wzorcem zachowania, do którego niedostosowanie było trudniejsze i straszniejsze niż realne niebezpieczeństwo. Aby zachować zimną krew wśród ogólnej paniki, trzeba by być bodaj bohaterem. Ale spróbujcie krzyczeć i szarpać się, kiedy wszyscy wokół robią spokojnie, co do nich należy - wymaga to szczególnego zuchwalstwa” (tamże: 190-192). Gdzie indziej z kolei pisze: „Zamiast szarpać się spazmatycznie - odnaleźć automatyzm ruchów. Automatyzm to dobrze rozwiązane zadanie, a dokładność jego rozwiązania czuje się w mięśniach i głowie" (tamże: 183-1849).

Fakt, że wojna sama w sobie była doświadczeniem totalnym zarówno dla jednostki, jak i całej zbiorowości, był dla myślicielki dość oczywistą konstatacja, którą chłodno potrafiła sformułować w jednym zdaniu: „Charakterystyczna w tych pierwszych dniach była niewiedza przemieszana z wieloletnim natręctwem myśli o nieuchronności i druzgocącej totalności zdarzenia oraz przygotowaniem na nie" (tamże: 172). Lidia Ginzburg

\footnotetext{
9 Tu Lidia Ginzburg wprost odcina się od zaproponowanej przez Wiktora Szkłowskiego antymieszczańskiej w wymowie koncepcji nowego widzenia świata czy też wyzwalania oglądu rzeczywistości z automatyzmu i rutyny przy pomocy chwytu literackiego (zob. Szkłowski 2006).
}

\section{/ 114 STANRZECZY 1[16]/2019}


bardzo sprawnie jednak potrafiła wniknąć w anatomię tej totalności, aby pokazać jej mechanizmy. Jej zdaniem to nietypowe wojenne działania oraz ryzyko, jakie za sobą niosły, stanowiły o totalności tego doświadczenia: „W oblężonym Leningradzie widzieliśmy wszystko, ale najrzadziej - strach. Ludzie z lekceważeniem słuchali świstu przelatujących nad głowami pocisków. Oczekiwać, że uderzy, oczywiście, jest trudniej; ale wszyscy wiedzieli - jego gwizd słyszą tylko ci, w których tym razem nie uderzył" (tamże: 190). Według Ginzburg stanowić o nim miało, oprócz opisanego wyżej poczucia społecznej przydatności, a więc czegoś abstrakcyjnego, także nieoczekiwane dogłębne poznanie własnego ciała, jego ograniczeń i możliwości, potencjału pełnego odłączenia od świadomości, rozdwojenia lub nawet całkowitej utraty kontroli na nim: ,,[... zima ciało było niewyczerpanym źródłem potencjalnych cierpień ze swoimi nowymi ostrościami i wystającymi żebrami [...]. Zima, gdy ludzie odkrywali w sobie kość za kością, coraz wyraźniejsze stawało się wyobcowanie, rozszczepienie wewnętrznej świadomości woli i ciała - jako przejawu wrogiego świata zewnętrznego" (tamże: 175).

Ten problem wydawał się szczególnie istotny ze względu na głód, jakiego doświadczyli leningradczycy, a który również pozbawił życia matkę Lidii Ginzburg:

En przeoczył poczatek strasznej epopei głodowej miasta - jak i wielu innych, którzy na początku stosunkowo lekko traktowali narastające ograniczenia. Zdziwił się (lubił się dziwić), kiedy ktoś powiedział: „Oto on - głód...”. [...] Potem przyszedł czas, kiedy nie dostrzegać już się nie dało. Wokół umierali ludzie [...]. O pierwszych przypadkach śmierci znajomych jeszcze rozmyślano (mój znajomy? W biały dzień? W Leningradzie doktor nauk? Z głodu?) (tamże: 200-201).

Dalej pisze: „Jedzenie stało się sprawą intymną i okrutną” i „przestało istnieć w kontaktach międzyludzkich" (tamże: 203). Ginzburg obserwowała proces, w którym człowiek oblężony nie chciał i nie mógł dzielić się jedzeniem, co w owym czasie mogło przyczynić się do śmierci kogoś innego - stąd aspekt okrucieństwa w akcie spożywania posiłku. Z drugiej strony, zagłębiała się w świat ludzkich fantazji, analizując pragnienia związane z potrzebą zaspokojenia głodu, w których ,jedni oddawali się surrealistycznemu doświadczeniu pieczonej gęsi [...]. Inni marzyli o tym, 
żeby dużo zjeść, dużo więcej niż jadali teraz. Pragnęli w nieskończoność przedłużać dostępne im doświadczenia smakowe" (tamże: 203-204).

Zapiski człowiek a oblèzonego poruszają jeszcze wiele interesujących i nieoczywistych dla literatury odnoszącej się do wspomnień wojennych obserwacji i analiz, jak np. tych o charakterze genderowym, podkreślającym znaczenie kulturowego wymiaru płci ${ }^{10}$ :

Wyjątkowo źle znoszą stanie w kolejkach mężczyźni, przyzwyczajeni do tego, że ich czas poddawany jest szacunkom. Rzecz nawet nie w obiektywnej ocenie, a raczej w odziedziczonych odruchach. Pracujące kobiety odziedziczyły po swoich babkach i matkach czas, którego się nie liczy. Rzeczywistość nie daje zaniknąć temu atawizmowi. Mężczyzna uważa, że po pracy należy mu się odpoczynek i rozrywka; kobieta po powrocie z pracy zaczyna pracę w domu. Kolejki czasu blokady wpisały się w wieloletni plan rzeczy wydawanych, zdobywanych, w zwyczajową irytację i nawykową kobieca cierpliwość (tamże: 192-193).

Czy tych o charakterze estetycznym, które w sposób ironiczny i intertekstualny polemizuja z dawnymi fascynacjami autorki: „Codzienne marszruty biegną wzdłuż poharatanych w różny sposób domów. Są ruiny natarczywie przypominające konstrukcje meyerholdowskie" (tamże: 185). Ta rozpiętość tematów i traktowanie doświadczenia wojny jako pretekstu do podjęcia rozważań nie tylko natury etycznej, ale także estetycznej oraz introspektywnej w połączeniu z chłodną analizą swoich wcześniejszych fascynacji intelektualnych także świadczy o wielowymiarowości i totalności koncepcji Ginzburg.

\section{/// Totalność: wymiar 3. Literatura w poszukiwaniach rzeczywistości}

Jedną ze swoich ostatnich książek Litieratura w poiskach riealnosti (Literatura w poszukiwaniach rzeczywistości) (1987), stanowiącą zbiór artykułów, esejów oraz notatek tworzonych od lat 20. do 80. XX wieku, Ginzburg w słowie wstępnym podzieliła na część teoretyczna, ale wspieraną, „konkretnym materiałem historycznym", oraz wspomnieniowo-eseistyczną. Jednocześnie skomentowała ten podział jako niekategoryczny:

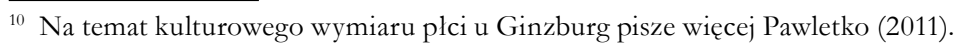


Między gatunkami obu części nie odczuwam dystansu niemożliwego do przejścia. Wszystko to jest dla mnie odmiana prozy. W moich książkach literaturoznawczych z ostatnich dwudziestu lat także jest mowa o życiowych problemach i psychice człowieka. Czasem eseistyka w sposób naturalny przechodziła u mnie $\mathrm{w}$ narrację, nawet $\mathrm{z}$ umownymi fikcyjnymi bohaterami. Sa mi oni potrzebni w charakterze obiektu analizy tych czy innych faktów duchowego doświadczenia (Ginzburg 1987: 2).

Taki wybór obrazuje przyjęty przez nią model, w którym elementy z pozoru sprzeczne, jak twórczość literacka i praca teoretyczna, przenikaja się i dopełniają. Ginzburg najbardziej lubiła pracować i myśleć pomiędzy gatunkami (Žolkovskij 1989: 83) i to stanowi o totalności przyjętego przez nią paradygmatu myślenia.

W efekcie poruszania się pomiędzy różnymi stylami, epokami, postaciami Ginzburg nie pozostawiła jednak po sobie jedynie eklektycznego zbioru pism o różnej tematyce, ale spójną wewnętrznie oryginalną teorię literatury pośredniej (promię̇utocznaja litieratura). Impulsem do podjęcia rozważań nad tą koncepcją było poczucie nieadekwatności wczesnych idei formalistycznych, czy szerzej awangardowych, skupionych na autoteliczności literatury oraz autonomiczności sztuki w zetknięciu z nową rzeczywistością społeczną, w jakiej przyszło wszystkim funkcjonować już po rewolucji październikowej. O ile sam okres okołorewolucyjny odpowiadał, zdaniem Ginzburg, formom wypracowywanym przez futurystów oraz opracowywanym przez formalistów, to czas pierwszej pieciolatki pokazał, że słowo jest bardziej niż kiedykolwiek uwikłane historycznie ${ }^{11}$, a jednostka musi bardziej niż kiedykolwiek podjąć pracę psychologiczną, która miałaby ja zakorzenić w nowych warunkach społecznych. Jak słusznie zauważa Ilja Kukulin, „to ona zrobiła krok od badania form literackich do zrozumienia polityki literackiej i stojącej za nią świadomości” (Kukulin 2015), który był krokiem ku pozaliterackiej rzeczywistości. Dlatego właśnie Ginzburg poszukiwała najbardziej odpowiedniej formy literackiej (gatunku, stylu), który dobrze oddawałby to przesunięcie, jakie nastapiło w warunkach osiadania nowych instytucji, jednocześnie nie mieszając się w tocząca się ów-

\footnotetext{
${ }^{11}$ Nie oznacza to jednak, że formaliści byli ahistoryczni. Jak piszą Burzyńska i Markowski, „Formalizm powstawał jako teoria esencjalistyczna i powoli ewoluował w stronę historyczności rozumianej wszelako immanentnie, ograniczonej do zmian w obrębie systemu literackiego. Formaliści unikali badania odniesień tekstu literackiego do pozaliterackiej rzeczywistości, choć Szkłowskiego teorię chwytu można interpretować jako nowoczesną teorię doświadczenia estetycznego jako takiego" (2009: 125-126).
} 
cześnie w łonie inteligencji dyskusję, w której trzeba było opowiedzieć się po jednej ze stron (rozwój vs degradacja kultury).

Wspomniana wyżej niechęć do nazywania samej siebie po prostu literaturoznawczynią również związana była z jej podejściem do pracy. Swobodne poruszanie się między dyscyplinami, bez wskazywania tej głównej i tych pomocniczych, sprawiło, że funkcjonowała ona poza władzą konkretnej dyscypliny, realizując idee wolności twórczej w tak zhierarchizowanym świecie radzieckiej nauki i literatury. Najważniejszymi owocami takiego podejścia były jej dwie duże monografie O psichotogiczeskoj prozie (O prozie psychologicznej) oraz O litieraturnom gieroje (O bohaterze literackim). O pierwszej mówiła jako o najbardziej intymnej spośród swych książek, poruszała w niej bowiem najważniejsze problemy życia, analizowane w twórczości najważniejszych dla niej autorów, wśród których byli Wissarion Bieliński, Marcel Proust, Lew Tołstoj, Stendhal czy Gustave Flaubert. Druga natomiast była przestrzenią, w której w całej świetności ujawniły się jej zainteresowania zachodnią psychologią i socjologią, odwoływała się tam m.in. do Karola Marksa, Maxa Webera, Zygmunta Freuda czy Carla Junga (Van Buskirk, Zorin 2012: 13).

Propozycja teoretyczna Ginzburg powstawała nie tylko poprzez odbicie się od wcześniejszych fascynacji koncepcjami modernistów, ale także w ramach dyskusji z obowiązującymi wówczas koncepcjami literaturoznawstwa marksistowskiego, które przecież również proponowało uwzględnianie społecznego zaplecza literatury. Myślicielka, choć z dużą uwagą czytała dzieła Marksa, nigdy jednak nie uznawała marksizmu jako wystarczającego projektu dla badań literackich. Wulgarny marksizm eksponował nadmiernie determinizm społeczny oraz koncepcję, w której literatura byłaby odbiciem rzeczywistości społecznej. Ja interesowało coś więcej, a mówiąc konkretnie - to, jak kształtują się normy estetyczne i etyczne w nowych warunkach społecznych: „literatura współczesna ma tylko jedno zadanie - wyrazić los człowieka jako społecznie uwarunkowany" (Ginzburg 2002: 122-123). Zdaniem Sawickiego:

Ginzburg argumentuje, że realiów lat 30. nie można rozumieć jedynie jako systemu totalnej presji ideologicznej. Jej zdaniem, doświadczenie społeczne ludzi, którzy byli świadkami kształtowania się nowego społeczeństwa, odzwierciedlało życie w ZSRR bardziej autentycznie niż oficjalna ideologia. Nowa literatura realistyczna miała reprezentować egzystencjalne doświadczenie jednostki w społeczeństwie kolektywistycznym, relacje między osobą 
prywatną a środowiskiem społecznym, gdzie ludzie musieli zrezygnować ze swoich przedrewolucyjnych nawyków i przestrzegać nowych zasad wspólnotowego życia (Savitsky 2012: 270).

Oznacza to, że w sytuacji skrajnej niepewności i niejasności co do kierunku, w jakim nowa formacja społeczna się rozwinie, Ginzburg zadawała już pytania natury fundamentalnej, jak te o kształt nowego, wspólnego dla wszystkich imaginarium kulturowego w Związku Radzieckim. Pytała w tym kontekście np. o znaczenie i sposoby radzenia sobie ze śmiercia w nowym ateistycznym społeczeństwie, nawet w sytuacji, w której nie jest się „wierzącym komunistą” (tamże: 271).

Innym napięciem, jakie interesowało Ginzburg w jej pracy teoretycznej, ale również realizowanym praktycznie w jej twórczości, było przenikanie się tego, co prywatne (intymne, własne), z tym, co społeczne (uogólnione, wspólne). Dla teoretyczki intymne przeżycia były zawsze historyczne i zanurzone w przestrzeni społecznej i kulturowej. Doświadczenie własne traktowała jednocześnie jako typowe, była reprezentantka trendów i tendencji: „Śmiem myśleć, że nie sięgam do głębi jako takiej i w ogóle nie zajmuję się sobą. Odbieram/odczuwam siebie jako kawałek wyrwany z mięsem społecznej rzeczywistości, który udało się pokazać jako część rzeczywistości, wyjątkowo wygodny dla obserwacji” (Ginzburg 2002: 99-100).

Dla syntetycznego określenia teoretycznej i literackiej spuścizny Lidii Ginzburg badacze używaja dwóch zbliżonych określeń. Według Sawickiego jest to literackie swiadectwo rzeczywistości (Savickij 2013: 117), z kolei Van Buskirk określa ją mianem Literatury w poszukiwaniach rz̨eczywistości (Van Buskirk 2016). Ta totalna w swojej strukturze i treści formuła realizuje się we wspomnianej wyżej koncepcji literatury pośredniej, w której:

[...] efekt artystyczny jest tworzony nie przez inwencję, ale przez selekcję i kompozycję oraz przez specyficzną mieszankę opisu i refleksji na temat ludzkiej natury, psychologii, etyki i historii. [Ginzburg] Starała się osiagnąc swoje cele, opracowując wyrafinowane quasi-naukowe metody analizy siebie i swojego najbliższego otoczenia, szkicując i rozcinając postaci ludzi wokół siebie oraz starannie, w sposób stenograficzny, rejestrując ich rozmowy (Van Buskirk 2016: 7-8). 


\section{/// Podsumowanie}

Unikatowa koncepcja literatury pośredniej realizowała się nie tylko w sferze teorii literatury i kultury, ale miała swoje praktyczne przełożenie w twórczości Lidii Ginzburg. Pisarka, traktując samą siebie jako typową przedstawicielkę swego pokolenia oraz obserwując swoje bezpośrednie otoczenie, zdołała pozostawić po sobie obszerną pod względem ilościowym oraz dogłębna jakościowo metaanalizę bumanistycznej inteligencji sowieckiego typu. Jak się zdaje, to właśnie było celem jej intensywnej pracy twórczej, w której ramach sięgała po warsztat wypracowany przez historię, psychologię, socjologię oraz naukę o literaturze, chociaż do tej ostatniej dyscypliny miała największy dystans.

Lidia Ginzburg nie zawsze jednak była tak typowa, jaką chciała się widzieć. Przez cały okres swojej twórczości prowadziła „dwoistą rozmowę - o życiu i literaturze”. Przy tym odczuwała „,[...] dwojaki niepokój: jeśli literatura - znaczy, że zajmuję się nie tym, co ważne; jeśli życie - zajmuję się nierealizowalnym" (Ginzburg 2002: 269). Poruszanie się pomiędzy tym, co jawi się jako nieprzystawalne, było sensem jej działalności, a jednocześnie źródłem cierpienia. Zawodowe zajmowanie się literaturą było w jej rozumieniu pasożytnictwem, żerowaniem na cudzym rozumieniu życia, ale jednocześnie było to pasożytnictwo konieczne, ponieważ można było je realizować, w przeciwieństwie do innych wymiarów życia. W jednym z późnych esejów z 1978 roku zauważa nawet: „Umysł działa nadal, ale zerwała się emocjonalność pracy, tak jak zrywa się głos. Emocje, bez których nawet najbardziej racjonalna osoba nie może rozwiązać nawet najbardziej analitycznego problemu" (tamże: 269). Można wobec tego domniemywać, że spełnienie twórcze, jakiego bez wątpienia doświadczyła, szło w parze z wyczerpaniem emocjonalnym, spowodowanym niespełnieniem w życiu prywatnym.

Wspomniana przez nią nierealizowalność życia zawierała się m.in. w niemoźliwości pełnego i szczerego opowiedzenia o bólu „bardzo dosłownego, bardzo totalnego" wyrzeczenia się miłości (tamże: 269). Ginzburg nie znalazła sposobu, w jaki mogłaby wprost opowiedzieć nie tylko o swojej odmiennej orientacji seksualnej, ale także o poczuciu braku, jakiego z tego powodu doświadczała. Nierealizowalność i niemożliwość spełnienia miłości w życiu kompensowała jej spełniona miłość do literatury, o której potrafiła pisać z wrażliwością i czułością, przy zachowaniu jednoczesnej analitycznej ostrości. W takim właśnie rozumieniu Lidia Ginzburg była intelektualistką totalna, dla której szeroko rozumiana dwoistość była 
nieodzowną częścią każdej tożsamości - indywidualnej i zbiorowej - i, co najważniejsze, składnikiem jej sprawczości.

Bibliografia:

/// Burzyńska A., Markowski M.P. 2009. Teorie literatury XX wieku. Podrecznik, Wydawnictwo Znak.

/// Gessen M. 1997. Dead Again: The Russian Intelligentsia after Communism, Verso.

/// Ginzburg L. 1932. Agentstvo Pinkertona, Molodaâ gvardiâ.

/// Ginzburg L. 1964. O lirike, Sovetskij pisatel'.

/// Ginzburg L. 1971. O psibologičeskoj proze, Sovetskij pisatel'.

/// Ginzburg L. 1979. O literaturnom geroe, Sovetskij pisatel'.

/// Ginzburg L. 1982. O starom i novom, Sovetskij pisatel'.

/// Ginzburg L. 1987. Literatura v poiskah real'nosti. Stat'i, èsse, zametki, Sovetskij pisatel' Leningradskoe otdelenie.

/// Ginzburg L. 1989. Čelovek qa pis'mennym stolom, Sovetskij pisatel'.

/// Ginzburg L. 1991. Pretvorenie opyta, Avots, Novaâ literatura.

/// Ginzburg L. 1999. Zapisnye kni ̌̌ki, Zaharov.

/// Ginzburg L. 2002. Zapisnye knižki. Vospominaniâ. Èsse, Iskusstvo-SPB.

/// Ginzburg L. 2007. Raboty dovoennogo vremeni: Stat'i. Recenzii. Monografiâ, Petropolis.

/// Ginzburg L. 2011. Prohodâsie haraktery: Proza voennyh let. Zapiski blokadnogo čeloveka, Novoe izdatel'stvo.

/// Ginzburg L. 2013. Zapiski çłowieka obleżonego, [w:] J. Koczyna, O. Bergholc, L. Ginzburg, Oblężone, tłum. A. Knyt, Ośrodek Karta, PWN, s. $171-206$.

/// Grajewski W. 2005. Fenomen Freudenberg, [w:] O. Freudenberg, Semantyka kultury, red. D. Ulicka, Universitas, s. VII-XXXVI. 
/// Kochetkova I. 2010. The Myth of the Russian Intelligentsia Old Intellectuals in the New Russia, Routledge.

/// Komisaruk E. 2014. Audiosfera oblę̇onego Leningradu (na materiale „Driennikón” Olgi Berbolc i „Zapiskón cąłowieka obleżonego” Lidii Ginæburg), „Przegląd Rusycystyczny", nr 148(4), s. 27-38.

/// Kukulin I. 2015. Častnyj čelovek: L. A. Ginzburg v konce 1920-b-načale 1930-h godov by Stanislav Savickij (review), „Ab Imperio”, 2015(2), s. 479-490.

/// Kumpan E. 2016. Bližnij podstup ke legende, Žurnal Zvezda.

/// Kumpan K. 2011. Institut istorii iskusstv na rubeže 1920-b- 1930-hgg. http:// pushkinskijdom.hoststandart.ru/wp-content/uploads/sites/12/2018/03/ Kunpan_Instituty-2011.pdf; dostęp: 16.03.2020.

/// Kušner A. 2002. Prâmoj razgovor o žiznini, [w:] L. Ginzburg, Zapisnye kniそ̌ki. Vospominaniâ Ėsse, Iskusstvo-SPB, s. 5-10.

/// Nahirny V. 2018. The Russian Intelligentsia. From Torment to Silence, Routledge.

/// Pawletko B. 2011. Kategoria żeńskości / inności w twórczości Lidii Ginz̧burg, „Rusycystyczne Studia Literaturoznawcze”, nr 21, s. 70-80.

/// Read C. 1979. Religion, Revolution and the Russian Intelligentsia 1900-1912: The Vekhi Debate and Its Intellectual Background, The Macmillan Press.

/// Savickij S. 2013. Častnyj čelovek. L. Â. Gin₹burg v konce 1920-b-načale 1930-h godov, Izdatel'stvo Evropejskogo universiteta v S.-Peterburge.

/// Savitsky S. 2012. Reflection as an Ethical Value (Lydia Ginzburg's "The Thought that Drew a Circle"), [w:] Lydia Ginzburg's Alternative Literary Identities. A Collection of Articles and New Translations, red. E. Van Buskirk, A. Zorin, Peter Lang, s. 263-282.

/// Sdvižkov D. 2011. Epoka inteligencji. Historia porównawcza warstwy wylesz̨tatconej w Europie, tłum. J. Górny, Wydawnictwo Neriton.

/// Szkłowski B. 2006 [1986]. Szztuka jako chwyt, tłum. R. Lużny, [w:] Teorie literatury XX wieku. Antologia, red. A. Burzyńska, M.P. Markowski, Wydawnictwo Znak, s. 95-111.

/// Tô̂enko Ž.T., red. 2019. Sud'by rossijskoj intelligencii: prošloe, nastô̂see, budusee, Rossijskij gosudarstvennyj gumanitarnyj universitet. https://www. rsuh.ru/upload/main/sf/RGGU_2019_PRINT.pdf; dostęp: 31.10.2019. 
/// Uspenskij B.A., red. 1997. Russkaâ intelligenciâ $i$ rapadnyj intellektualizm: Istoriâ i tipologiâ, O.G.I.

/// Van Buskirk E. 2016. Lydia Ginzburg's Prose: Reality in Search of Literature, Princeton University Press.

/// Van Buskirk E., Zorin A., red. 2012. Lydia Gin₹burg's Alternative Literary Identities. A Collection of Articles and New Translations, Peter Lang.

/// Zarycki T. 2008. Kapitat kulturowy. Inteligencja w Polsce $i$ w Rosji, Wydawnictwa Uniwersytetu Warszawskiego.

/// Žolkovskij A. 1989. Cel'nost'. O tvorčestve L.Â. Ginz̧burg, „Literaturnoe obozrenie", 1989(10), s. 78-86.

\section{/// Abstrakt}

Artykuł dotyczy wielowymiarowej twórczości rosyjskiej teoretyczki literatury, kultury, a także autorki wspomnień i dzienników - Lidii Ginzburg (1902-1990), która była świadkiem najbardziej newralgicznych momentów dwudziestowiecznej historii ZSRR/Rosji. Urodzona w Odessie, pochodziła z inteligenckiej, żydowskiej rodziny. Kształciła się w Leningradzie w latach 20., otoczona bardzo żywym ówcześnie, pluralistycznym środowiskiem intelektualnym i twórczym. Dotknięta przez stalinowskie represje, przeżyła wojenną blokadę Leningradu. W artykule problematyzowany jest splot trzech wymiarów totalności, które ukonstytuowały tę niebanalna myślicielkę. Pierwszy z nich to totalność doświadczeń biograficznych (represje, oblężenie miasta), drugi to totalność instytucji, w ramach których tworzyła i pracowała (totalitarny Związek Radziecki, cenzura) oraz trzeci, czyli totalność jej myśli i koncepcji, które przekraczały granice dyscyplin i obszarów działalności (precyzyjna i dążąca do kompletności twórczość naukowa oraz refleksyjna, emocjonalna i otwarta w swej formie twórczość wspomnieniowa - dzienniki, listy i zapiski). Totalność traktowana jest w artykule jako nierozerwalność teorii i praktyki, racjonalności i emocjonalności, abstrakcyjnych idei i prywatnego doświadczenia oraz innych przeciwstawnych sobie kategorii.

Słowa kluczowe:

Lidia Ginzburg, Związek Radziecki, Rosja, inteligencja, totalność 


\section{/// Abstract}

\section{Three Dimensions of Totality: The Work of Lydia Ginzburg}

This article concerns the multidimensional work of Lydia Ginzburg (1902-1990), a Russian literary and cultural theoretician and author of memoirs and diaries, who witnessed the most momentous events in the Soviet Union. The author of the article discusses the intersection of three dimensions of totality characterizing this remarkable thinker. The first was her biographical experience (the repressions, the siege of the city). The second concerns the institutions within which she worked (the totalitarian Soviet Union, censorship). The third was the nature of her thoughts and concepts, which crossed the boundaries of various disciplines and forms of activity (her academic work aimed at completeness and precision; her emotional, reflective memoirs were open in form). "Totality" is understood in this article as the inseparability of theory and practice, of rationality and emotionality, of abstract ideas and private experience.

Keywords:

Lydia Ginzburg, the Soviet Union, Russia, the intelligentsia, totality

/// Katarzyna Roman-Rawska - doktor nauk humanistycznych. Filolożka i socjolożka, tłumaczka, badaczka współczesnej literatury i kultury rosyjskiej oraz ich związków z polityką. Autorka monografii Nowy realizm w rosyjskim polu literackim po 1991 roku. Literatura i polityka (Warszawa 2020). Pracuje w Instytucie Slawistyki PAN.

ORCID: https://orcid.org/0000-0003-3851-3971

E-mail:k.roman.rawska@gmail.com 